Island Studies Journal, Vol. 11, No. 2, 2016, pp. 601-618

\title{
Different shades of green on small islands
}

Teresa Tiago

University of the Azores

Ponta Delgada, Portugal

maria.tp.tiago@uac.pt

Sandra Dias Faria

University of the Azores

Ponta Delgada, Portugal

sandra.mc.faria@uac.pt

João Luís Cogumbreiro

University of the Azores

Ponta Delgada, Portugal

jcogumbreiro@me.com

João Pedro Couto

University of the Azores

Ponta Delgada, Portugal

joao.pa.couto@uac.pt

and

Flávio Tiago

University of the Azores

Ponta Delgada, Portugal

flavio.gb.tiago@uac.pt

\begin{abstract}
Many small islands exist as tourism destinations worldwide. In the 1990s, the growth of environmental consciousness led some small islands to question their mass tourism offers and to refocus on more sustainable propositions. However, it remains unclear whether hospitality firms see these sustainability related efforts as drivers of success and whether tourists value this dimension when choosing or recommending a destination. This study chose a small island destination to address these questions using data covering firm and tourism perceptions of green products. The results show that tourists tend to value green efforts with different intensities, corresponding to three segments: Light Green, Green, and Super Green. These findings should help hotels adjust their communication strategies and develop new services. Further, destination marketing organizations can devise a consistent destination strategy, integrating all stakeholders by including their most valued concepts.
\end{abstract}

Keywords: green tourism; lodging; small islands; sustainable tourism; tourist buyer behaviour; niche tourism

(C) 2016 - Institute of Island Studies, University of Prince Edward Island, Canada. 


\section{Introduction}

The earth contains approximately 180,497 islands of different sizes, political frameworks, geographical positions and natural resources (Tiago, Tiago \& Amaral, 2015). Differences apart, tourism is a major contributor to economic development in most cases, and especially for small islands where tourism is often the only industry showing consistent recent growth (Scheyvens \& Momsen, 2008). Catibog-Sinha (2015) adds that besides the economic impact of tourism, small-island tourism can generate positive externalities both in terms of funding, conservation commitment, and environment improvement, with spillovers in the creation of new and expanded networks of parks, forest preserves, biosphere reserves, recreational areas, beaches, waterfronts, and underwater trails, while providing environmental education to visitors and locals. However, some small island destinations can no longer offer sustainable tourism due to overuse and resource damage driven by tourism growth (Rodríguez, ParraLópez \& Yanes-Estévez, 2008).

Moreover, some attempts to promote a green tourism typology as a quality product have suffered from reduced visibility and credibility in tourists' eyes (Spring, 2002). Bohdanowicz (2006) warns that this consumer "devaluation" of green practices, reflected in much of the current proliferation of prizes, labels, and certifications that reduce credibility, leads hotel units to disregard "green" practices as a priority. These appear to explain why so many lodging firms step away from integrating sustainability concepts in their offer compositions. However, small islands have unique characteristics that must be considered, such as limited resources and environmental conditions that can impel lodging firms to adopt and value a more green approach (Catibog-Sinha, 2010; McElroy \& de Albuquerque, 2002).

In this context, it appears relevant to distinguish the importance attached to "green" values by tourists from tourism operators' vision of "green" practices. We thus chose the small island context to validate the perceptions of value of a hotel property with an environmentally friendly certification and buying behaviour of tourists who chose this property.

The paper is structured as follows. After an introduction, section 2 discusses the main issues related to small island tourism and the planning of sustainable offers, followed by an analysis of the dimensions that tourists value when choosing a travel destination. The third section presents the research method and data treatment, while the last section presents the main conclusions and suggests directions for future research.

\section{Background}

The tourism system consists of different elements including tourists, target regions, visitor generating regions, transit routes, and the tourism industry consisting of businesses and organizations involved creating tourism products (Cooper, 2012). As the literature points out, tourism is an activity quite suitable to small islands, given their natural resources, peripheral locations, and unique attractions. However, tourism continues to be one of the most resourceconsuming activities (Cater \& Goodall, 1992) and given the range of constraints noted in a small island context (Carlsen, 1999), it is useful to consider tourism sustainability practices and measure cost-benefit accountability.

Tourism researchers have explored small island tourism development for many years, an interest motivated by a recognition of its importance to these regions (Scheyvens \& 
Momsen, 2008). As Butler (2002, p. 88) posits, "small islands, for a variety of reasons, have long been viewed as attractive destinations for both recreational and touristic purposes."

As Goeldner and Ritchie (2006) note, this type of tourism is unique as it provides a wide range of benefits, such as job creation, local income, providing funds to protect natural areas, and preserving environmental heritage to attract more tourists.

Regardless of the attractiveness and benefits noted by Keane, Brophy, and Cuddy (1992), tourism growth in small islands can severely strain local capacity and resources. Therefore, balancing these dimensions can be complex and needs careful governance.

Tourism supply and demand follows an asymptotic curve characterized by slow initial growth, followed by faster growth until it reaching a maturity phase (Wilkinson, 1987). There are two possible outcomes thereafter: decline or market rejuvenation. The evolution of tourism on small islands follows a pattern similar to other products and services in a product life cycle. Similarly, Lundberg (1980) presented a six-phase model: rapid growth, short-run success, awareness of problems, tourism recession, serious difficulties, and reflection.

Researchers have adopted all of these models, conferring different types of approaches to tourism offers, as shown in Figure 1.

\section{Figure 1: Tourism Life Cycle studies.}

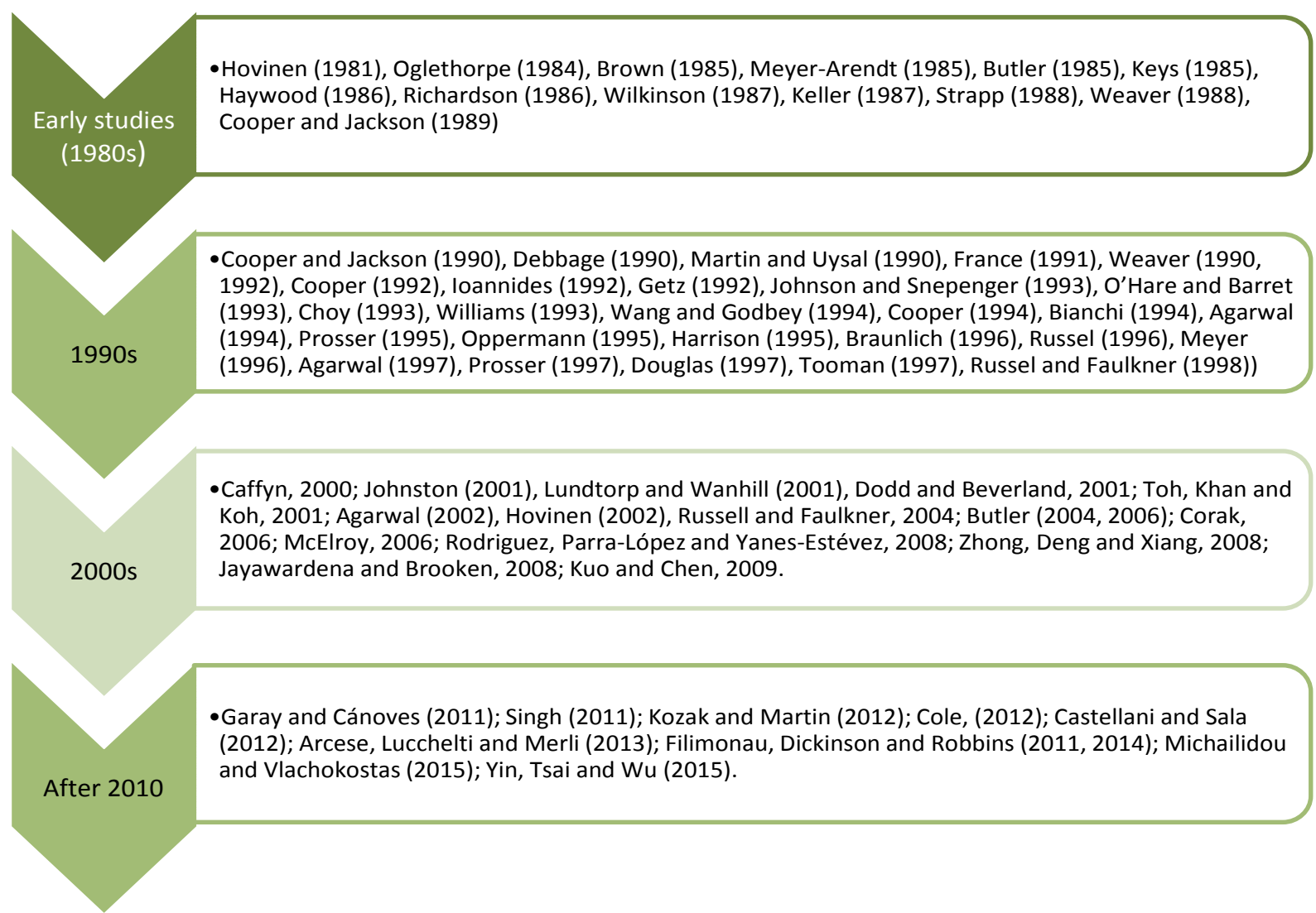

Yet most of these works focus on other tourism realities, and those focusing on islands choose mature destinations, which need to rethink and reshape their offers. Studies of the variety and distinctiveness of a destination's products show that planning the offer was crucial for overcoming the last two phases and to boosting tourism in the initial phases (Cooper \& Hall, 2013). Hall (2008) presents five forms of planning destinations must consider: boosterism, an 
economic approach, a physical approach, community-orientation, and a sustainable approach. This last approach requires a transformation of traditional sustainable principles into effective planning (Cooper \& Hall, 2013).

Therefore, over the past decade, driven by the increasing competitiveness and attractiveness of tourism activities worldwide, many studies focus on differentiation and specializations of tourism practices and activities in certain segments or niches (Gotham \& Lewis, 2015). Starting from the notion that a "tourism niche" is a fragment of demand upon which consumers' desires and preferences can be explored and tapped, an offer differentiation strategy can encourage new product development, one of which is linked to the environmental component, variously described as green tourism, sustainable tourism, ecotourism, and nature tourism, among others.

There are distinct strategies destinations can deploy to advance a sustainable approach (Hall, 2008). From the six-phase model, our attention focuses on raising customer and producer awareness, which are central elements in a small island destination context.

On the producer awareness side, it is possible to reach sustainability through a combination of regulatory or voluntary initiatives. For instance, many producers have adopted codes of conduct and good practices to create a "greener" tourism offer. In this sense, environmental certifications have emerged as universal eco-labels, certifying best practices and achievements.

The environmental issues were related primarily to industries directly polluting the environment. Later, between the 1980s and 1990s, environmental pressure increased visibility, reaching a wider range of industries (Kirk, 1995; Chan \& Wong, 2006).

According to Klassen and Whybark (1999), environmental management systems are infrastructure investments that affect production management. These systems include efforts to formalize procedures to assess environmental impacts during budgetary decisions, to increase management stakeholders' involvement, to improve staff training to prevent and reduce waste, and to establish an environmental department. However, to date, there is no universally accepted definition or set of indicators for sustainability in the tourism industry, making sustainable tourism a difficult and much debated concept from a business point of view.

For more than a decade, researchers have called for a paradigm shift in marketing, focusing more on the consumer (Grönroos, 2004; Grönroos \& Gummerus, 2014). Now, a growing number of publications are refocusing the attention on consumer perspective, specifically consumer niches, such as green consumption.

Though the first articles published on green consumer behaviour date back to the 1970s, most are studies of American citizens who consider themselves environmentalists regardless of their buying behaviour (Mainieri, Barnett, Valdero, Unipan \& Oskamp, 1997; Roberts, 1996; Shrum, McCarty \& Lowrey, 1995). For the last few decades, as the relevance of environmental protection has increased, this type of green consumption has become a major issue for consumer-oriented marketers.

The first considerations relate to tourism products and the nature of the clients. So looking at tourism products as experiences where consumption takes place over four distinctive stages: pre-consumption experience; purchase experience; core consumption, and remembered and nostalgia experience (Arnould, Price \& Zinkhan, 2002).

In the pre-consumption experience phase, the would-be tourist searches for information on a destination and bases travel plans on personal preferences and criteria. It is thus a truly important stage when looking at tourists' green consumer behaviour. The research in this field 
is quite new and dates back to the late 1990s (Gayle, 2002; Kalafatis, Pollard, East \& Tsogas, 1999; Laroche, Bergeron \& Barbaro-Forleo, 2001). In this domain, the denomination of "green" is alternatively substituted with "eco-friendly," "nature-based," "environmentally responsible," or "environmentally friendly" (Han, Hsu \& Lee, 2009).

To Kotler (2015), customers are more aware, active, and powerful than ever. Aiming not at products, but experiences, these customers look for emotions and affects, closer to a new phase referred to as marketing 3.0 targeting more spirit-driven consumers such as green consumers.

Over the years, researchers have developed numerous models to define the elements that determine and influence consumer behaviour related to green product consumption (see Table 1).

Table 1: Green consumer behaviour: determinants and influencers.

\begin{tabular}{|l|l|l|}
\hline Criteria & Indicators & Authors \\
\hline $\begin{array}{l}\text { Demographics \& } \\
\text { environmental } \\
\text { knowledge }\end{array}$ & $\begin{array}{l}\text { Gender, age, income, } \\
\text { education }\end{array}$ & $\begin{array}{l}\text { Shrum et al. (1995) } \\
\text { Steg, Dreijerink \& Abrahamse } \\
\text { (2005) }\end{array}$ \\
\hline Psychographics & Attitudes and values & $\begin{array}{l}\text { Minton and Rose (1997) } \\
\text { Steg et al. (2005) } \\
\text { Sheth, Sethia \& Srinivas (2011) }\end{array}$ \\
\hline Firms & $\begin{array}{l}\text { Promotion, } \\
\text { advertisement, labeling, } \\
\text { packaging, } \\
\text { environmental } \\
\text { accreditation }\end{array}$ & $\begin{array}{l}\text { Nicosia (1966) } \\
\text { Buckley (2002) }\end{array}$ \\
\hline Other influencers & $\begin{array}{l}\text { Culture, family, friends, } \\
\text { opinion-leaders }\end{array}$ & Childers \& Rao (1992) \\
\hline
\end{tabular}

Other studies indicate an influence from traditional segmentation variables (sociodemographics and psychographics) on consumers' buying decisions related to green products (Sheth et al., 2011; Steg et al., 2005; Shrum et al., 1995).

However, a tourist is much more than a consumer, since tourists actively seek experiences matching their expectations and motivations. Therefore, a green tourist is not only searching for good experiences, but above all looking at sustainability concerns as a way of life and choosing destinations based on their "green" image (Chon, 1990).

For a destination, especially small islands, delivering and composing these green experiences involves integrating endemic resources with infrastructure and a strategy that envisages a "green offer" for target markets. One tool available to deliver a green image is environmental accreditation. Nonetheless, the literature shows that ecolabels and environmental accreditation are controversial (Buckley, 2002).

Regardless of the fact that certification originated in the manufacturing industry (Font, 2002) in the 1990s, it followed a similar pattern to the evolution of green consumer behaviour. The European Commission defined standards in 1993 and recognized these through the EcoManagement and Audit Scheme (EMAS). EMAS and other certifications present sets of codes 
of practice, manuals, and awards so eco label-related efforts will improve firms' and tourist actions, as well as awareness toward the environment.

Pinto (2005) lists the principal benefits for lodging and hospitality firms to implement an environmental management system according to existing certification systems, such as economic benefits, cost savings, reduced water consumption, increased recycling and waste recovery, reduced production of effluents and pollution, decreased frequency and severity of environmental accidents, reduced fines and penalties for environmental breaches, increased revenue, increased market participation from product innovation and lesser competition, new product lines for new markets, and increased process efficiency and other strategic benefits. Yet, many firms find tourism eco labels quite expensive, time consuming, and focusing only on hotels or ecotourism providers (Synergy, 2000). Additionally, eco labels seem to have limited marketing power, questioning tourist awareness and lodging firms' willingness to invest in these strategies.

Despite the numerous studies conducted in this domain, only a few in the nonEuropean context analyze green tourism offers on small islands. Considering that sustainable tourism on small islands encompasses a significant shift in tourism thinking from both demand and supply perspectives, it seems relevant to focus on green awareness, perceived customer value, and lodging firms' commitment to green certification.

\section{Research framework}

The literature review indicates that from a lodging perspective, there are dimensions influencing more sustainable management practices sensitive to phenomena associated with environmental impacts and the organization's involvement in its local community.

The literature suggests that tourists' 'green' behaviour can be measured both at the time of purchase decision and at the time of product or service consumption, such as the preference for a local product over an imported product or the choice of indicating whether a towel should be washed by its placement in a room. Subsequently, tourists can also be persuaded to prefer a more environmentally friendly product when perceiving material, emotional, or circumstantial advantages.

Tourist profiles have changed over the past few years due to personal characteristics and environmental pressures. This scenario increased the challenges most destination managers and firms face in their efforts to develop a tourism product that accurately fits their targets.

In evaluating green hotels in Taiwan from a consumer perspective, Tang (2015) found a strong relationship between buying decision, attitude toward environmental certification (green), and customer satisfaction. In addition, the author identified recycling as one of the most relevant issues in his study.

Therefore, in attempting to broaden the scope of the analysis, to fully understand the changes in this sphere, and to generate knowledge that can serve to support or reposition current offers, this study adopts the approach illustrated (see Figure 2). 


\section{Figure 2: Methodological approach.}

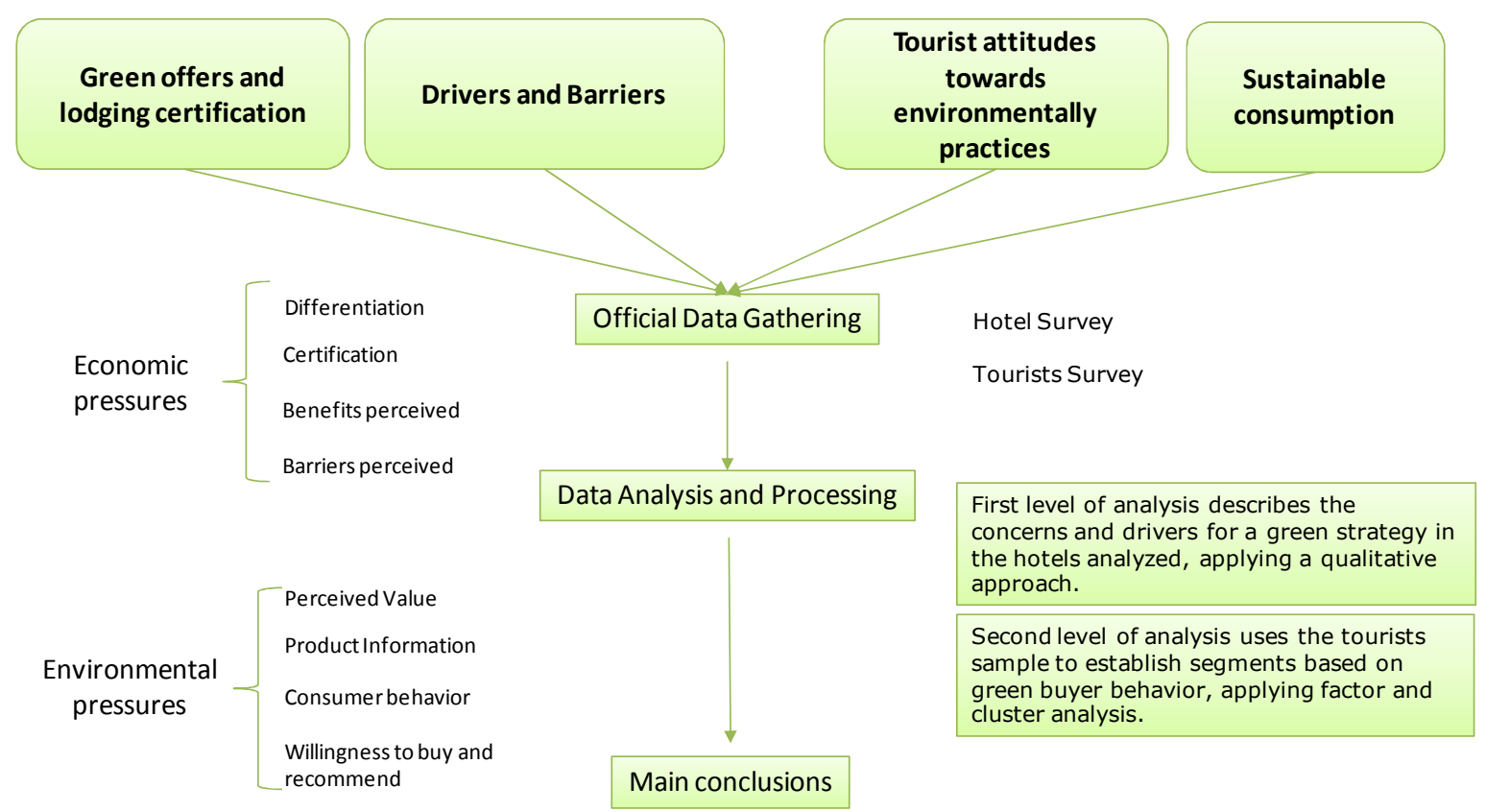

Different profiles of green tourism

With the increasing importance of various dimensions of sustainability, one must note the need for additional considerations when converting to green tourism offers given the fact that tourism offers are combinations of services and not products, implying a different notion of buying and being green.

With the link between personal antecedents and choices a particularly interesting one, this study focuses on these triggers as decision factors in the buying process.

Two sets of research questions were formulated, with the first one primarily aiming to understand travelers' preferences and hospitality strategies related to green certification:

Q1. What are hotels' main concerns related to green certification?

To substantiate further the potential impact of travelling preferences on tourist behaviour, the second set of questions focuses on more specific issues related to the buying process, including:

Q2. To what extent do travelers' green preferences influence their buying behaviour?

Q3. What are the main decision influencing factors?

Most past studies use the Caribbean region as the study context, with their findings confirmed in other countries as well. To further understand small island tourist behaviour and to determine the major factors that influence green certification, we conducted market segmentation, grouping tourists according to their similarity in terms of green consciousness and awareness. The results are presented below. 


\section{Data treatment and results}

The increasing interest in small islands as tourism destinations challenges destination marketing organizations to identify the key elements that make up the "place," valuing its dynamic nature and all tourism resources. Nowadays, some traditional small island destinations present a mature offer and therefore have been widely studied (Carlsen, 1999; Font, 2002). This is not true for small island destination in Europe, especially for the Azores, one of the "outermost regions," and which will be the case study in this research.

Data for this study came from two surveys in the Azores. The first was conducted on São Miguel Island, the largest of its nine islands having a wider tourism heritage. Located in the middle of the northern hemisphere of the Atlantic Ocean, in an area approximately $600 \mathrm{~km}$ (373 miles) wide, the Azores archipelago hosts a variety of landscapes and spectacular volcanic scenery and is a popular destination for whale watching and for travelers who enjoy having one of the most offbeat travel experiences in Europe, walking, and appreciating nature. As noted by Behrens and Gaigné (2006), the Azores' nine small islands are remote and suffer from insularity constraints as well as topography and climate difficulties, combined with exposure to natural disasters. This small island economy relies on a few products, with tourism being one of the strategic industries recently chosen by local government to sustain its development. However, as these authors point out, this is counter-balanced by the Azores' favorable natural conditions, which include rich geothermal resources and beautiful landscapes and beaches.

Therefore, resources to develop a nature-based tourism industry exist across the Azores. Its tourism industry is relatively recent, going back to the 1930s with the appearance of Terra Nostra, a company created in 1933 with the objective of promoting "São Miguel in the eyes of the tourist world, contributing...to its progress and development" (Ferreira, 1999). Since 1898, there are references in the "Traveler's Guide on the island of São Miguel" to the urgent and beneficial need "to attract the World cultured and moneyed interest to our potential, to the exceptional geographical and climatic conditions, given the wealth of mineral waters and the beauty of the volcanic landscape of São Miguel Island..."

Despite such significant reflections, in terms of tourism, the Azores only recently started boosting its tourism offering. Remoteness worked for several decades as a "fortress," preventing a nascent mass-tourism offering from developing but encouraging unique tourism experiences centered on tourist activities related to nature on all nine islands. Comparing the Azorean offering with that of another ultra-peripheral region of Europe - the Canary Islands, which is in a mature growth phase - seems especially valid, since the Azores have recently entered a fast growth phase, having recognized the need to reshape their offer in a more sustainable way (Rodríguez et al., 2008).

In terms of its tourism offering, the Azores intended to increase the number of visitors by promoting local natural conditions. However, the increasing use of natural resources and preservation needs may be conflicting interests, implying that all stakeholders should be concerned and involved. Sustainable tourism is a relational phenomenon requiring as little pressure on the environment as possible, along with visitors' increased awareness of nature sustainability principles (Cooper \& Hall, 2013).

The Canarian Archipelago, an autonomous community in the Spanish State, comprises seven islands of volcanic origin and, like the Azores, is an outermost region of the European 
Union. It is located south of Spain's mainland coast, and is influenced by its proximity to the Northwest of Africa. Visitors to the Canaries can enjoy good weather throughout the year, with it being a typical example of a "sun, sand and sea" destination that has over the years created and projected an image of "competitively priced holidays focused on the sun and beach mass tourism experience" (Scherrer et al, 2009, p.454; also Garin-Muñoz, 2006).

The Canary Islands' inbound tourism market is varied, but highly concentrated on tourists from Germany and Britain, that represent almost two thirds of the market. Holland, Sweden, Ireland, and Norway are other relevant markets. In terms of hospitality, the islands include traditional hotels as well as rented apartments, and property ownership and timesharing are widespread; the average length of stay on these islands is unusually high (Garin-Muñoz, 2006).

Tourism in Canaries represents $50 \%$ of GDP, and its massification reflects a commercial development with smaller sustainability concerns. In the past decade, the implementation of several initiatives has aimed to reverse this situation and convert the Canaries into a more sustainable destination (Rodriguez et al., 2008).

\section{Table 2: The Azores Islands versus the Canary Islands.}

\begin{tabular}{|c|c|c|}
\hline Compared Dimensions & Azores (Portugal) & Canaries (Spain) \\
\hline $\begin{array}{l}\text { Product life cycle } \\
\text { (Lundberg, 1980) }\end{array}$ & Fast Growth & $\begin{array}{l}\text { Maturity / awareness of } \\
\text { problems }\end{array}$ \\
\hline Island characteristics & $\begin{array}{l}9 \text { volcanic islands } \\
\text { Main industries: agriculture, } \\
\text { dairy farming (for cheese } \\
\text { and butter products } \\
\text { primarily), livestock } \\
\text { ranching, fishing, and lately } \\
\text { tourism (average of } 1 \\
\text { million visitors per year) }\end{array}$ & $\begin{array}{l}7 \text { islands } \\
\text { Main industries: tourism } \\
\text { (average of } 12 \text { million } \\
\text { visitors per year) }\end{array}$ \\
\hline Past offer type & Niche tourism & Mass tourism \\
\hline Current offer strategy & $\begin{array}{l}\text { Boosterism and sustainable } \\
\text { tourism approach }\end{array}$ & $\begin{array}{l}\text { Economic and sustainable } \\
\text { approach }\end{array}$ \\
\hline Sustainability paradigm & $\begin{array}{l}\text { Several sustainability } \\
\text { awards received in the last } 4 \\
\text { years } \\
\text { Hotels certificated with } \\
\text { EMAS: } 2 \text { units }\end{array}$ & $\begin{array}{l}\text { Need to reshape the offer } \\
\text { (Rodríguez et al., 2008) } \\
\text { Hotels certificated with } \\
\text { EMAS: } 4 \text { units }\end{array}$ \\
\hline Lodging typology & $\begin{array}{l}\text { Hotels; apartment hotel; } \\
\text { hostel and cottage or lodge }\end{array}$ & $\begin{array}{l}\text { Hotels; apartment hotel; } \\
\text { resort hotel; motel; hostel; } \\
\text { cottage or lodge }\end{array}$ \\
\hline
\end{tabular}

Thus, examining perspectives for both tourists and local firms on the sustainability of tourism offers is quite relevant, enabling the strategic planning actors as well as the firms' managers to establish coherent and consistent green offers. 
The initial survey targeted hotels managers in several units in Europe in terms of EMAS certification. Considering our aims, this study is limited to an analysis of the main concerns of hotels in São Miguel and the Canarias.

In the case of the Azores, the hotels that were analyzed are located in the main city in São Miguel, and are the only hotels in the archipelago with EMAS certification. These are four-star hotels, belonging to the same chain. The Canaries hotels that were analyzed have different characteristics: three of the hotels are holiday resort hotels, while the other is a city hotel. Two of the properties are family business units, and only one is owned by a hotel chain. The city hotel is considered a medium-size hotel, while the resort hotels all have more than 100 rooms. All the hotels that were analyzed have more than 10 years of EMAS certification.

Figure 2 illustrates the main motivations for adopting a green certification as illustrated in a word cloud generated using the software Tagxedo. This cloud reflects concerns about prevention, preservation, environmental reputation, and environmental impact minimization with a sustainable financial return.

The relevance given to certification is evident when looking at the consistent answer from all hotels that besides EMAS, they have also adopted other eco labels, such as The Green Leaf. Hotel managers consider the performance benefits from attaining greener products, stakeholder participation, and transparency. For the Canaries, managers stated that eco labeling could also improve reputation. No one mentioned customer orientation or customer demand as a motivation for adopting a green certification or practices.

\section{Figure 1: Word cloud regarding hotel managers' motivations.}

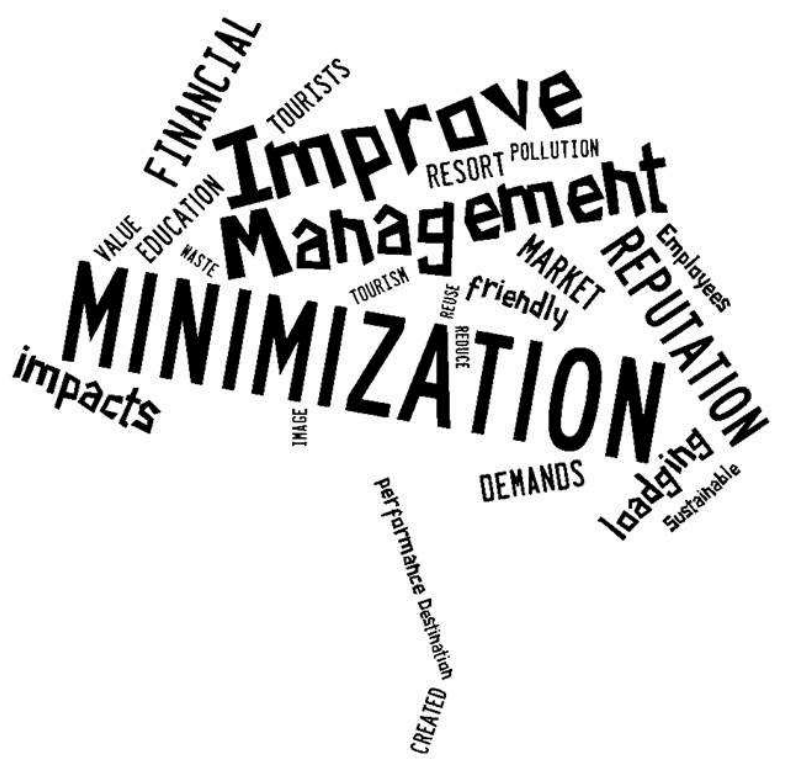

The second survey was conducted with tourists of one EMAS-certificated unit. The sample was composed mostly of men (54\% of respondents), working in the private sector and from a different set of countries, most from Portugal (48\%), as shown in Figure 3. 
Figure 3: Sample composition by country of origin.

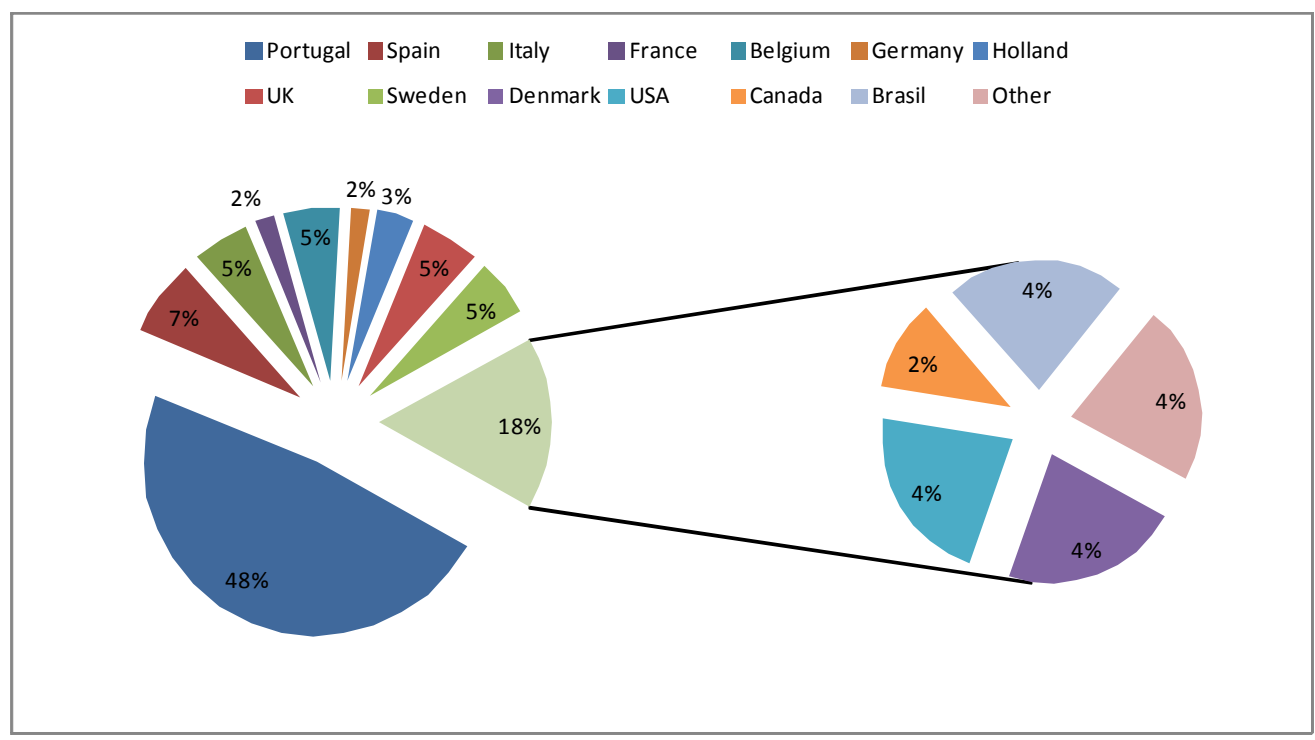

To identify the sub-segments within the green tourism market, we applied a non-hierarchical clustering method. This statistical approach possesses a monotonically increasing ranking of strengths, as clusters themselves progressively become members of larger clusters (Figure 4).

\section{Figure 4: Dendrogram.}

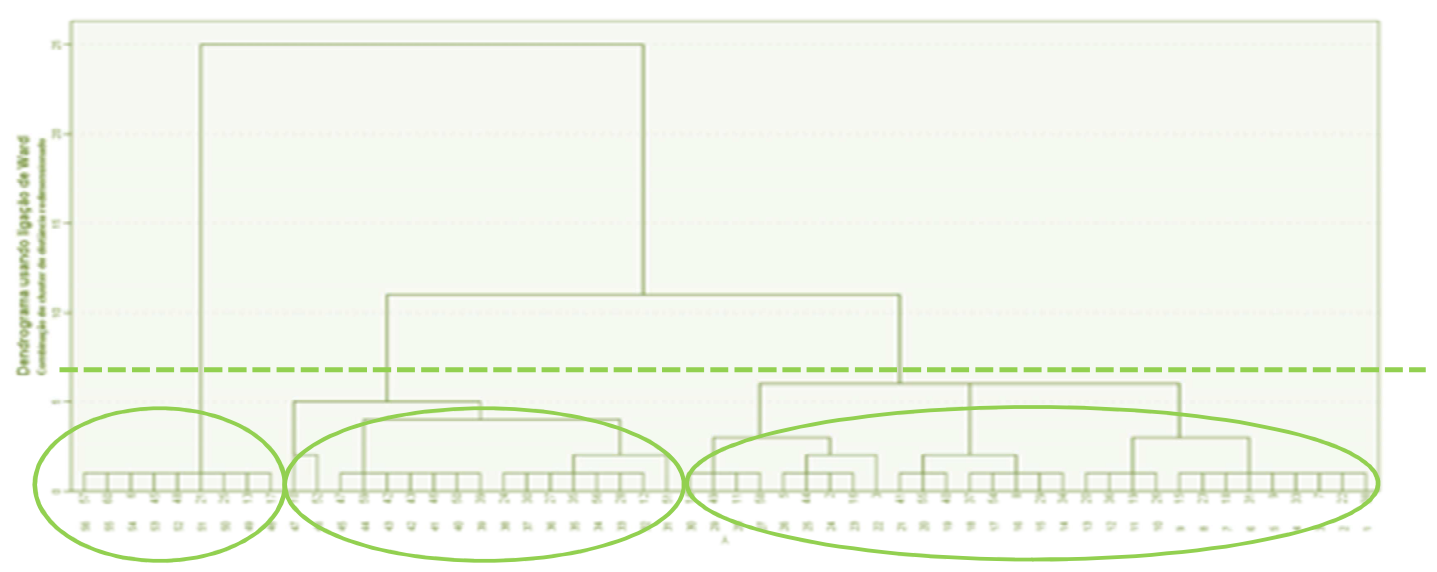

To apply cluster analysis, we consider a set of questions acknowledging the existence of EMAS criteria in practice by the hotel as dependent variables, measured according to the following indicators: waste sorting (e.g., paper, glass, and plastic), electricity consumption, gas and fuel consumption, water consumption, staff training and attitudes toward the environment, the flag and certificate in the lobby of the hotel, and the bar and restaurant menu offering green suggestions.

Applying the aforementioned methodology, the analysis found three groups named according to the range of dimensions present in each: 
- Cluster 1: Green

- Cluster 2: Super Green

- Cluster 3: Light Green

The Green Cluster identifies the most common practices and associations with domestic life, but not leading to a more comprehensive dimension on a global scale. The Super Green Cluster was more sensitive to the phenomenon, rating a higher importance and relevance, and demonstrating a positive sense, regarding organizational efforts toward a more sustainable society and consciousness.

The Light Green Cluster had the smallest expression in the sample, and shows green concerns related to adding value to the offers but are doubtful of the impact of the efforts made by people, organizations, and communities to protect the environment (e.g., low achievement in the responses on gas and fuel consumption since it is not visible in operations).

Looking into the members of the clusters, we can observe that women tend to have a more green-friendly behaviour. In terms of age, people less than 25 years of age and people over 65 years of age show less green behaviour. Regarding professional occupation, people working in the private sector and people that are self-employed tend to value green practices more. In general terms, higher education leads to greener behaviour.

Table 3: Sample profile.

\begin{tabular}{|c|l|c|c|c|}
\hline \multicolumn{2}{|c|}{ Demographics } & Light Green & Green & Super Green \\
\hline \multirow{4}{*}{ Gender } & Female & $47.1 \%$ & $43.3 \%$ & $66.7 \%$ \\
\cline { 2 - 5 } & Male & $52.9 \%$ & $56.7 \%$ & $33.3 \%$ \\
\hline \multirow{4}{*}{ Age categories } & Under 25 & $11.8 \%$ & $6.7 \%$ & $0.0 \%$ \\
\cline { 2 - 5 } & $26-45$ years old & $58.8 \%$ & $36.7 \%$ & $66.7 \%$ \\
\cline { 2 - 5 } & $46-65$ years old & $17.6 \%$ & $50.0 \%$ & $33.3 \%$ \\
\cline { 2 - 5 } & Over 66 & $11.8 \%$ & $6.7 \%$ & $0.0 \%$ \\
\hline \multirow{5}{*}{ Education } & Public Sector & $61.5 \%$ & $23.1 \%$ & $15.4 \%$ \\
\cline { 2 - 5 } & Own & $7.7 \%$ & $61.5 \%$ & $30.8 \%$ \\
\cline { 2 - 5 } & Private & $25.0 \%$ & $60.0 \%$ & $15.0 \%$ \\
\cline { 2 - 5 } & Other & $30.0 \%$ & $70.0 \%$ & $0.0 \%$ \\
\cline { 2 - 5 } & Secondary School & $20.0 \%$ & $60.0 \%$ & $20.0 \%$ \\
\cline { 2 - 5 } & High School & $37.5 \%$ & $50.0 \%$ & $12.5 \%$ \\
\cline { 2 - 5 } & Professional School & $23.5 \%$ & $64.7 \%$ & $11.8 \%$ \\
\cline { 2 - 5 } & Bachelor Degree & $50.0 \%$ & $50.0 \%$ & $0.0 \%$ \\
\cline { 2 - 5 } & Master Degree & $31.3 \%$ & $43.8 \%$ & $25.0 \%$ \\
\cline { 2 - 5 } & Doctorate & $0.0 \%$ & $50.0 \%$ & $50.0 \%$ \\
\hline
\end{tabular}

The tourists' country of origin also shows a distinctive pattern between cluster members. In this sense, the countries with a higher presence of "super green" are Sweden, USA, Belgium and Portugal. The 'green cluster' members belong mostly to Canada, Denmark, Germany, France and Spain. 


\section{Figure 5: Cluster distribution by country of origin.}

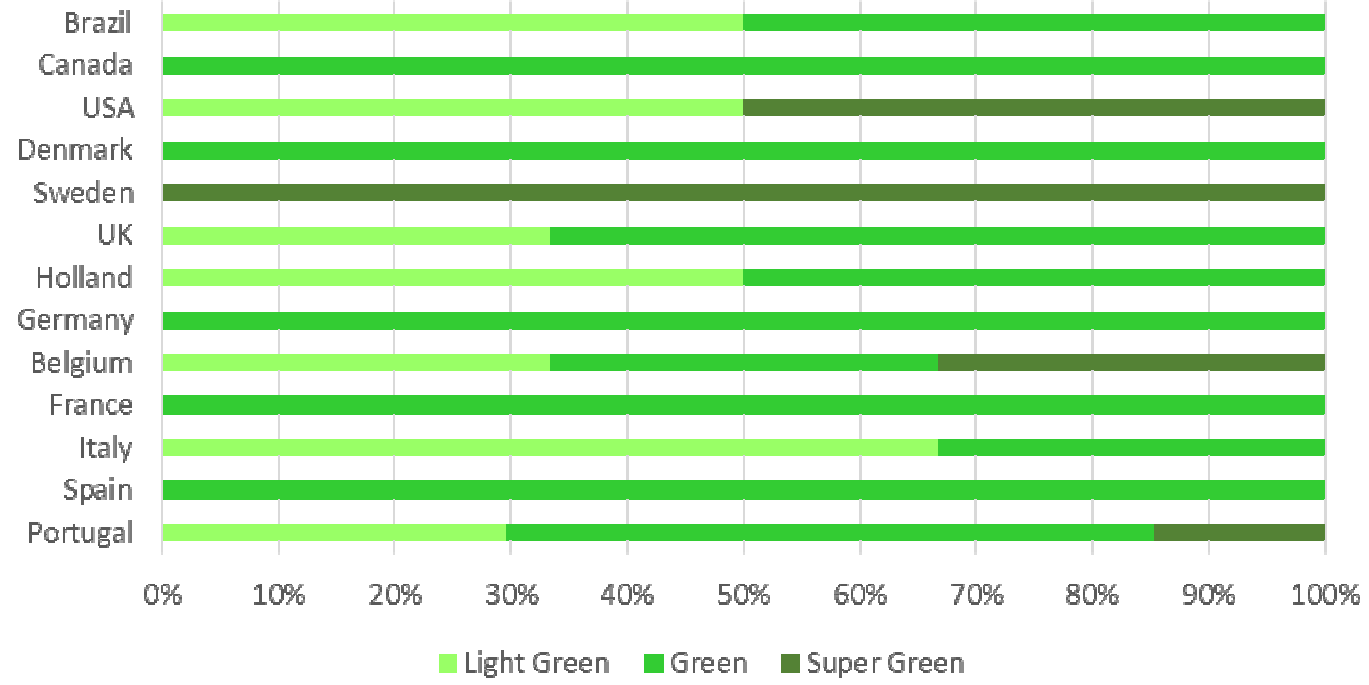

To validate the hypotheses, we conducted a test of homogeneity of variances and obtained the following results (see Table 4).

\section{Table 4: Homogeneity of variances test.}

\begin{tabular}{|l|c|c|c|c|}
\hline & Levene & df1 & df2 & Sig. \\
\hline Hotels' green certificate influences buying decision & 30,853 & 2 & 53 & 0.000 \\
\hline Would you recommend hotels with green certification? & 5,343 & 2 & 50 & 0.008 \\
\hline
\end{tabular}

Levene's test was used to determine whether the three clusters have significantly different population variances, thereby demonstrating their suitability for the application of an ANOVA test if the values were significant. The ANOVA test was then conducted. The significance values $(0,082$ and 0,321$)$ suggest no significant differences between the three clusters in terms of the buying decision process and future recommendations. 
Table 5: ANOVA test.

\begin{tabular}{|l|c|c|c|c|c|c|}
\hline \multicolumn{2}{|c|}{} & $\begin{array}{c}\text { Sum of } \\
\text { Squares }\end{array}$ & df & Average & Z & Sig. \\
\hline \multirow{2}{*}{$\begin{array}{l}\text { Hotels' green certificate } \\
\text { have influence on } \\
\text { buying decision }\end{array}$} & Between groups & 10.248 & 2 & 0.624 & 20.628 & 0.082 \\
\cline { 2 - 7 } & Inside & 120.591 & 53 & 0.238 & & \\
\cline { 2 - 7 } $\begin{array}{l}\text { Would you recommend } \\
\text { hotels with green } \\
\text { certification? }\end{array}$ & Total & 130.839 & 55 & & & \\
\cline { 2 - 7 } & Between groups & 0.044 & 2 & 0.022 & 10.164 & 0.321 \\
\cline { 2 - 7 } & Inside & 0.937 & 50 & 0.019 & & \\
\hline
\end{tabular}

However, looking closely at mean differences between clusters (Table 6$)$, the buying decision is more distinctive between clusters than the repurchase decision.

Table 6: Means difference between clusters.

\begin{tabular}{|l|l|c|c|}
\hline \multicolumn{2}{|l|}{ Ward Method } & Buying Decision & Repurchase Decision \\
\hline \multirow{4}{*}{ Tukey HSD } & Light Green & 1,47 & 1,00 \\
\cline { 2 - 4 } & Green & 1,53 & 1,06 \\
\cline { 2 - 4 } & Super Green & 1,11 & 1,00 \\
\hline \multirow{3}{*}{ Scheffe } & Light Green & 1,47 & 1,00 \\
\cline { 2 - 4 } & Green & 1,53 & 1,06 \\
\cline { 2 - 4 } & Super Green & 1,11 & 1,00 \\
\hline
\end{tabular}

In summary, the results reveal some of the concerns of hotels regarding green certification. Also, several conclusions can be drawn in terms of travelers' green buying profile and the factors that influence this behaviour. Age, gender, and occupation are relevant factors in distinguishing cluster membership. Also, the country of origin of tourists is quite significant, with Sweden, USA, Belgium, and Portugal (Super green cluster) being those that attach the most value to the green certification of hotels.

\section{Conclusion}

This research aimed to integrate different perspectives on tourism analysis. On the one hand, green certification was moot, since this is no longer a trend but rather a prerequisite for destinations aiming to survive and become sustainable in the future. However, we added two views to this notion, specifically lodging firms within and tourists visiting small islands since small islands are fertile grounds for tourism but are constrained by geographical location and resource availability.

Earlier studies indicate that tourism can enhance activity for small islands, especially ultra-peripheral islands, but can simultaneously have adverse effects on the environment. 
Balancing these dimensions is a challenge requiring strategic analysis and eventual incorporation into all stakeholders' daily activities.

In this sense, looking at tourists and lodging and hospitality firms is a promising field, and this study adopted the small island context to determine the drivers and motivations for these two sets of players. The Azores and Canary Islands were chosen as both archipelagos consist of several small islands with tourism as a strategic sector. In the Azores, tourism is in the early phase of development, so the insights from this study may help policymakers and managers create present and future offers. The Canaries are in a different situation, given that for many years, these Spanish islands attracted high tourist numbers, leading to the destruction and depletion of some of their natural resources. Acknowledging these facts led researchers to propose a rethinking of the Canaries' offering based on sustainable tourism. Once more, the results of this study can help destination marketing organizations fully understand both tourist and lodging firms in terms of green certification.

The overall objectives of this work were achieved by identifying different subgroups of 'green' behaviour in tourists and hoteliers.

Lodging firms' main motivations behind obtaining green certification on small islands relate to preservation, preventing degradation, and environmental reputation. In both archipelagos, independent of the tourism life cycle phase, eco labeling is not considered mandatory or customer-driven. These hotels consciously chose EMAS and other green certification as a strategic option to differentiate from competitors and to adopt a marketing 3.0 approach.

To summarize this study's results, there are three green tourist profiles: those who value it, but consider it mostly a marketing and promotion strategy (light green); those who are aware of its best practices and value it (green); and, those who show a deep concern about the environment and are aware of the hotels' various green activities (super green). The distinct subgroups require a specific marketing approach. However, regardless of the group, green certifications for lodging are a common decision variable in the purchase decision process; also, when recommending the hotel to friends and family no significant differences exist between groups. This may be driven by the fact that in the Azores, tourists expect no less: they are on a truly green island that often displays a wide range of shades of green in its nature and history.

This study fills a gap in the research of green tourism in small islands in Europe. The classification of "light green," "green," and "super green" permits us to better understand the characteristics and influence the choice of destination and hotel selection.

Several managerial implications can be drawn from this study, thereby providing insights for hotel managers, policymakers, planners, and tourist operators regarding the behaviour of green tourists. Considering the profiles of each subgroup, we derive the following managerial implications for hospitality and tourism:

(i) Since female tourists tend to be more concerned with green practices, hotels should target their strategy and marketing communication at this segment, paying attention to physical details in loco.

(ii) Considering that tourists between 25 and 45 years old are especially concerned with green practices, the tourism offerings for these groups should focus on increasing the awareness of the practices already taken, and on providing opportunities for further suggestions. 
(iii) Since tourists under 25 years of age as well as those over 66 years of age tend to attach less value to the green efforts, hotels should maintain their green practices, but focus their communication on the global value of this approach to customers and promote awareness.

(iv) When targeting tourists from Sweden, USA and Belgium, operators should concentrate their efforts on "super green," and their strategy should be centered on emphasizing the green practices and the hotel's green culture and certification.

Given the green behaviour patterns found in the buying behaviour with respect to other products and services in Europe (Couto et al., 2016), the tourism market can be expected to experience an increase in green preferences in the near future, and that small islands could benefit from a more sustainable and greener approach.

This field clearly needs further work to examine this phenomenon more deeply and to add to the results found for the Azores and the Canaries. Thus, while this research produces some interesting insights, a number of issues call for future research.

\section{Acknowledgements}

We gratefully acknowledge financial support from "Fundação para a Ciência e Tecnologia" (FCT - Portugal), national funding through research grant (UID/SOC/04521/2013) of the Advance/CSG, ISEG and Centre of Applied Economics Studies of the Atlantic - Project ACORES-01-0145-FEDER-000017 from AÇORES 2020, through FEDER - European Union.

\section{References}

Arnould, E. J., Price, L., \& Zinkhan, G. M. (2002). Consumers. New York: McGrawHill/Irwin.

Bianchi, R. V. (2004). Tourism restructuring and the politics of sustainability: A critical view from the European periphery (The Canary Islands). Journal of Sustainable Tourism, 12(6), 495-529.

Bohdanowicz, P. (2006). Environmental awareness and initiatives in the Swedish and Polish hotel industries: survey results. International Journal of Hospitality Management, 25(4), 662-682.

Buckley, R. (2002). Tourism ecolabels. Annals of Tourism Research, 29(1), 183-208.

Butler, R. W. (2002). Tourism development in small islands: past influences and future directions. In D.G. Lockhart, D. Drakakis-Smith, \& J.A. Schembri (Eds.), The development process in small island states (pp. 71-91). London: Routledge.

Carlsen, J. (1999). Tourism impacts on small islands: a longitudinal study of community attitudes to tourism on the Cocos (Keeling) Islands. Pacific Tourism Review, 3(1), 25-35.

Cater, E., \& Goodall, B. (1992). Must tourism destroy its resource base? In A.M. Mannion \& S.R. Bowlby (Eds.), Environmental issues in the 1990s (pp. 309-324). Chichester: Wiley.

Catibog-Sinha, C. (2010). Biodiversity conservation and sustainable tourism: Philippine initiatives. Journal of Heritage Tourism, 5(4), 297-309. 
Catibog-Sinha, C. (2015). The role of nature-based tourism in the green economy: a broader perspective for conservation and sustainability in the Philippines. In M.V. Reddy \& K. Wilkes (Eds.), Tourism in the green economy (pp. 57-70). London: Routledge.

Chon, K.-S. (1990). The role of destination image in tourism: a review and discussion. The Tourist Review, 45(2), 2-9.

Cooper, C. (2012). Essentials of tourism. London: Financial Times Press.

Cooper, C., \& Hall, C. M. (2013). Contemporary tourism: An international approach $\left(^{\text {nd }}\right.$ edn.). Oxford: Routledge.

Couto, J. P., Tiago, T., Gil, A., Tiago, F. \& Faria, S. (2016). It's hard to be green: reverse green value chain, Environmental Research, 149,302-313.

Font, X. (2002). Environmental certification in tourism and hospitality: progress, process and prospects. Tourism Management, 23(3), 197-205.

Gayle, D. J. (2002). Island tourism and sustainable development: Caribbean, Pacific and Mediterranean experiences. Westport CT: Greenwood Press.

Garín-Muñoz, T. (2006). Inbound international tourism to Canary Islands: a dynamic panel data model. Tourism Management, 27(2), 281-291.

Goeldner, C. R., \& Ritchie, J. B. (2006). Tourism: Principles, practices, philosophies. New York: John Wiley \& Sons.

Grönroos, C. (2004). The relationship marketing process: communication, interaction, dialogue, value. Journal of Business \& Industrial Marketing, 19(2), 99-113.

Grönroos, C., \& Gummerus, J. (2014). The service revolution and its marketing implications: service logic versus service-dominant logic. Managing Service Quality, 24(3), 206-229.

Hall, C.M. (2008). Tourism planning: Policies, processes and relationships. Edinburgh: Pearson Education.

Han, H., Hsu, L.-T. J., \& Lee, J.-S. (2009). Empirical investigation of the roles of attitudes toward green behaviour, overall image, gender and age in hotel customers' eco-friendly decision-making process. International Journal of Hospitality Management, 28(4), 519528.

Kalafatis, S. P., Pollard, M., East, R., \& Tsogas, M. H. (1999). Green marketing and Ajzen's theory of planned behaviour: a cross-market examination. Journal of Consumer Marketing, 16(5), 441-460.

Keane, M. J., Brophy, P., \& Cuddy, M. P. (1992). Strategic management of island tourism: the Aran islands. Tourism Management, 13(4), 406-414.

Klassen, R. D., \& Whybark, D. C. (1999). The impact of environmental technologies on manufacturing performance. Academy of Management Journal, 42(6), 599-615.

Laroche, M., Bergeron, J., \& Barbaro-Forleo, G. (2001). Targeting consumers who are willing to pay more for environmentally friendly products. Journal of Consumer Marketing, 18(6), 503-520.

Lundberg, D. E. (1980). The Tourist Business. Boston MA: CBI Publishing Inc.

Mainieri, T., Barnett, E. G., Valdero, T. R., Unipan, J. B., \& Oskamp, S. (1997). Green buying: The influence of environmental concern on consumer behaviour. Journal of Social Psychology, 137(2), 189-204.

McElroy, J. L., \& de Albuquerque, K. (2002). Problems for managing sustainable tourism in small islands. Island tourism and sustainable development: Caribbean, Pacific, and Mediterranean Experiences, (pp. 15-31). Westport CT: Greenwood Publishing Group. 
Roberts, J. A. (1996). Green consumers in the 1990s: profile and implications for advertising. Journal of Business Research, 36(3), 217-231.

Rodríguez, J. R. O., Parra-López, E., \& Yanes-Estévez, V. (2008). The sustainability of island destinations: Tourism area life cycle and teleological perspectives: the case of Tenerife. Tourism Management, 29(1), 53-65.

Scheyvens, R., \& Momsen, J. H. (2008). Tourism and poverty reduction: issues for small island states. Tourism Geographies, 10(1), 22-41.

Shrum, L. J., McCarty, J. A., \& Lowrey, T. M. (1995). Buyer characteristics of the green consumer and their implications for advertising strategy. Journal of Advertising, 24(2), 71-82.

Tiago, M. T., Tiago, F. G. \& Amaral, F. E. (2015). Food experiences: the oldest social network... Paper presented at 4th international conference on strategic innovative marketing, Mykonos, Greece.

Wilkinson, P. F. (1987). Tourism in small island nations: a fragile dependence. Leisure Studies, 6(2), 127-146. 